\title{
BIOCHEMICAL RESPONSES OF Digitaria commutata AND Cenchrus ciliaris TO WATER STRESS: ANTIOXIDATIVE REACTIONS, PROLINE AND SOLUBLE SUGARS ACCUMULATION
}

\author{
Taoufik Amari ${ }^{1}$ and Chedly Abdelly ${ }^{1}$
}

\begin{abstract}
The impact of water stress on antioxidant enzyme activities, proline, soluble sugars, and carotenoids contents found in Digitaria commutata and Cenchrus ciliaris plants was investigated. Two different watering regimes were used on plants over a period of three months. Water stress decreased total chlorophyll content in plants, but increased carotenoids content. Interestingly, no change was observed in the quantum yield of PSII photochemistry $\left(F_{v} / F_{m}\right)$. Malondialdehyde (MDA) content increased to a higher extent in both species. Enhanced activities of all the enzymes (peroxidase, catalase, and superoxide dismutase) studied, except for catalase in the roots were observed. Proline and soluble sugars contents increased significantly following water stress exposure. No clear differences were found between both species. The results link drought tolerance of Digitaria commutata and Cenchrus ciliaris plants with better capabilities of anti-oxidative system. Additionally, it is linked to the accretion of osmoprotectants proline and soluble sugars when exposed to drought.

Additional keywords: Antioxidative enzymes, carotenoid, proline, soluble sugars, water stress
\end{abstract}

\section{RESUMEN}

Respuestas de Digitaria commutata y Cenchrus ciliaris al estrés hídrico: reacciones antioxidativas, prolina y azúcares solubles Se investigó el impacto del estrés hídrico en la actividad de las enzimas antioxidantes, así como de prolina, azúcares solubles y carotenoides en plantas Digitaria commutata y Cenchrus ciliaris. Se utilizaron dos regímenes diferentes de riego durante un período de tres meses. El estrés hídrico disminuyó el contenido total de clorofila en las plantas, pero aumentó el contenido de carotenoides. Curiosamente, no se observó ningún cambio en el rendimiento cuántico del fotosistema PSII (Fv/Fm). El contenido de malondialdehído (MDA) aumentó en mayor medida en ambas especies. Se observe una actividad mejorada en todas las enzimas (peroxidasa, catalasa y superóxido dismutasa), excepto la catalasa en las raíces. Los contenidos de prolina y azúcares solubles aumentaron significativamente después de la exposición al estrés hídrico. No se encontraron diferencias claras entre ambas especies. Los resultados relacionan la tolerancia a la sequía de D. commutata y $C$. ciliaris con mejores capacidades del sistema antioxidante, así como también con la acumulación de los osmoprotectores prolina y azúcares solubles.

Palabras clave adicionales: Carotenoides, enzimas antioxidantes, estrés hídrico, proline, sólidos solubles

\section{INTRODUCTION}

Among environmental constraints, water stress is a significant threat to the plants. Today, water scarcity is listed as a serious global problem jeopardizing the aim to achieve sustainable agriculture. In the plant, water stress induces severe disturbances in the physiological processes, affecting vital functions and ultimately causing steep decline in agricultural output. Most evidently, water deficit is accompanied by growth retardation and inhibition of diverse metabolic processes including photosynthesis, respiration,

Received: June 7, 2020

${ }^{1}$ Laboratoire des Plantes Extrêmophiles, Centre de Biotechnologie de Borj-Cédria, BP 901, 2050 Hammam-lif, Tunisia. e-mail: taoufik.amari@gmail.com (corresponding autor); chedly.abdelly@gmail.com uptake/translocation of ions, and assimilation of nutrients. Water stress triggers a domino of molecular mechanisms, as it has been largely documented (Foyer and Noctor, 2004; PirastehAnosheh et al., 2016; Fang et al., 2017). More research has pointed towards a link between oxidative stress and exposure to drought conditions (Manivannan et al., 2008; Filippou et al., 2014; Laxa et al., 2019), as evident from the buildup in the concentration of Reactive Oxygen Species (ROS) $\left(\mathrm{OH}, \mathrm{O}_{2}{ }^{--},{ }^{1} \mathrm{O}_{2}, \mathrm{H}_{2} \mathrm{O}_{2}\right)$. These species can attack sensitive membranes and biomacromolecules causing damage at cellular level, 
protein oxidation, nucleic acid mutations, and lipid degeneration (Bian and Jiang, 2009; Choudhury et al., 2013; La et al., 2019). Water scarcity stress instigates oxidative pressure in view of restraint on photosynthetic action because of discrepancy between light captured and the amount used (Foyer and Noctor, 2004). Alterations are observed in functioning of chloroplasts in leaves of plants exposed to water stress. The consequence is the degeneracy of excess light captured leading to reactive oxygen species. Malondialdehyde (MDA), a by-product of degeneration of polyunsaturated fatty acids found in membranes, is considered a dependable indicator of oxidative stress (Demiral and Türkan, 2005). MDA is an important sign of membrane system injury. It is used as a biomarker of lipid peroxidation (Gawel et al., 2004; Moussa and Abdel-Aziz, 2008).

In order to cope with water stress plants have evolved numerous systems. These are mainly oxidative systems which are either enzymes based or are non-enzymatic. These systems can reduce oxidative damage caused to cells by scavenging ROS species. In all plants, mechanisms exist for detoxification of active oxygen species. These include stimulation of antioxidant enzymes e.g. superoxide dismutase (SOD) that catalyzes the $\mathrm{O}_{2} \cdot{ }^{-}$to $\mathrm{H}_{2} \mathrm{O}_{2}$ and $\mathrm{O}_{2}$ conversion and catalase (CAT) which breaks down $\mathrm{H}_{2} \mathrm{O}_{2}$ into water, a process that can also be carried out by a number of other peroxidases (Miller et al., 2010). Antioxidants which are Non-enzymatic include numerous compounds such as ascorbate (AsA), nitrogenous metabolites, phenols and carotenoids (Milvia, 2013; Laxa et al., 2019). Additionally, they comprise amino acids, among which proline is a powerful antioxidant activity which is needed to reduce the damaging effects of ROS (An et al., 2013; Ejaz et al., 2020). Adaptation of osmotic pressures using buildup of sugars (DelatorreHerrera et al., 2010; Zhang et al., 2014) and proline (An et al., 2013; Ejaz et al., 2020) is a common metabolic reaction of higher plants designed to maintain turgor pressure and avoid water stress.

Digitaria commutate and Cenchrus ciliaris are a perennial species, found mostly in warm regions of both hemispheres, growing in a wide range of habitats (Boukris and Chaieb, 1998). The goal of this study was to assess the antioxidant responses of $D$. commutate and $C$. ciliaris, when faced with water stress, through study of physiological responses related to lipids peroxidation and different antioxidant system. Morphophysiological changes of those perennial species when subjected to water stress were previously reported (Amari et al., 2017).

\section{MATERIALS AND METHODS}

Characteristics of soil. For the purpose of this research, soil was collected from a depth of $0-20$ cm depth in Gafsa, which is a city located in the south western region of Tunisia. Following attributes were found in soil sample: $\mathrm{pH}=7.4$; calcium ion (244.69 $\mu$ equiv. $\cdot \mathrm{g}^{-1}$ soil); potassium ion (0.41 $\mu$ equiv. $\cdot \mathrm{g}^{-1}$ soil); sodium ion (1.21

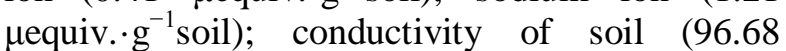
$\left.\mu \mathrm{s} \cdot \mathrm{cm}^{-1}\right)$ and organic particles $(0.87 \%)$. For the study a sample of $5 \mathrm{~kg}$ of dried soil was placed in imperforated pot and watered intensively with tap water over a period of two days. Evaporation was mitigated through use of aluminum cover placed on pot. Soil field capacity was measured after desiccation at $105{ }^{\circ} \mathrm{C}$ for 48 hours.

Plant material and culture conditions. Seed collection took place in vicinity of Bouhedma National Park (East of Tunis). Germination was conducted in pots filled with $2 \mathrm{~kg}$ of soil. 3 plants were placed in each pot. To study only water loss through leaf transpiration, aluminum foil was used for covering the pots four weeks into the experiment for preventing water loss via evaporation. As a control, 24 plants were subject to irrigation at 70 per cent of field capacity for 3 months. It was performed under natural sunlight and temperature to imitate conditions found in field.

Maximum efficiency of photosystem II. Measurements of mature leaves were recorded according to procedure outlined by Genty et al. (1989). Chlorophyll fluorescence measurements (6 replicates per treatment) were also recorded at the end of the experiment, before the last harvest. Measurements were taken at midday using a portable-modulated fluorimeter PAM-2000 (Walz, Germany). Leaves were dark-adapted for at least 20 min using leaf clips. Florescence level $\left(\mathrm{F}_{0}\right)$ was measured with $100 \%$ PSII reaction centers open by employing modulated light low enough not to induce variance in fluorescence. Maximal 
fluorescence level $\left(\mathrm{F}_{\mathrm{m}}\right)$ was measured by 0.8 saturating pulses at $8000 \mu \mathrm{mol} \cdot \mathrm{m}^{-2} \cdot \mathrm{s}^{-1}$ in darkadapted leaves. The values of $F_{0}$ and $F_{m}$ were then employed for determining variable fluorescence $\left(\mathrm{F}_{\mathrm{v}}=\mathrm{F}_{\mathrm{m}}-\mathrm{F}_{0}\right)$ and maximum efficiency of photosystem II $\left(F_{v} / F_{m}\right)$.

Chlorophyll content. Chlorophyll concentration of leaves of 6 replicates was measured through UV spectrophotometer employing the absorption spectra. Small pieces of fresh leaves weighing 300 $\mathrm{mg}$ were extracted and placed in $3 \mathrm{~mL} 80 \%$ acetone. As recorded by Lichtenthaler and Welburn (1983), measurements were made for extract absorption at 470, 646.8 and $663.2 \mathrm{~nm}$.

Lipid peroxidation estimation. A quick and easy method was deployed for the measurement of cellular oxidative stress. MDA production during the oxidation of polyunsaturated fatty acids was used as the basis of this method (Hodges et al., 1999). The technique accounts for the possibility of amalgamating the compounds in the thiobarbituric acid (TBA)-reactive substances assay. Fully expanded leaves were used for MDA contents. Ultrasonic cleaner was used to freeze dry samples extracted with 80-20 ethanol and water solution (Bransonic, Danbury, CT). 10-minute centrifugal treatment of homogenate at $15,000 \mathrm{~g}$ was employed. Following centrifuging, same solvent was used to re-extract pellet twice.

Analytical procedure of proline. For making measurements of proline, samples of frozen leaves and roots were used, homogenized in solution of 3 vol of $1 \mathrm{mM}$ tridecafluoroheptanoic acid (TDFHA), $50 \%(\mathrm{v} / \mathrm{v})$ methanol. Dual treatment was rendered to the samples, while they were first shaken for $10 \mathrm{~min}$ at $4{ }^{\circ} \mathrm{C}$, they were later centrifuged twice at $14,000 \mathrm{~g}$ for $20 \mathrm{~min}$ at $4{ }^{\circ} \mathrm{C}$. $0.5 \mathrm{mM}$ TDFHA, $25 \%(\mathrm{v} / \mathrm{v})$ methanol solution was used for dilution of underivatized supernatant. Agilent Technologies 1200 Series capillary pump along with aQ-TOF mass spectrometer was employed for LC-ESI-MS analysis, a technique already employed by Armstrong et al. (2007).

Soluble sugars content. Dissolvable sugars content was measured using Sturm et al. (2003) technique with some small adjustment utilizing liquid chromatography (HPLC) (Agilent Technologies 1200 arrangement) coupled with refractive index detector RID and Zorbax Carbohydrate $5 \mu \mathrm{m}$ segment $(4.6 \times 250 \mathrm{~mm})$. Test conditions: blend of mobile phase of acetonitrile with deionized water in proportion 65: $35(\mathrm{v} / \mathrm{v})$; consistent rate for stream of $0.8 \mathrm{~mL} \cdot \mathrm{min}^{-1}$; temperature of $30{ }^{\circ} \mathrm{C}$ was maintained. Samples of dried gel were set up by adding $2 \mathrm{~mL}$ of deionized water and blending for $1 \mathrm{~min}$.

Enzyme assays. Complete superoxide dismutase (EC 1.11.1.5) activity and associated activities were accessed according to Scebba et al. (1999). Gradually increased volumes $(5,10,20$, and $40 \mu \mathrm{L})$ of extracts of root and leaf were added to the mixture to achieve final volume of $3 \mathrm{~mL}$. The composition of reaction mixture was $50 \mathrm{mM}$ potassium phosphate buffer $(\mathrm{pH} 7.8), 0.1 \mathrm{mM}$ EDTA, $13 \mu \mathrm{mM} \cdot \mathrm{L}^{-1}$ methionine, $2 \mu \mathrm{M}$ riboflavin and $75 \mu \mathrm{M}$ NBT (nitroblue tetrazolium). Technique employed by Luck (1965) was used for measurement of the total catalase (EC 1.11.1.6) activity. As $\mathrm{H}_{2} \mathrm{O}_{2}$ was being consumed, a decline in absorbance was measured against a plant extractfree blank. The $3 \mathrm{~mL}$ mixture for the experiment contained $66 \mathrm{mM}$ sodium phosphate buffer $(\mathrm{pH}$ 7.0), to which $30 \%$ (w/v) $\mathrm{H}_{2} \mathrm{O}_{2}$ was added (optical density of 0.5 at $240 \mathrm{~nm}$ was achieved with a $1 \mathrm{~cm}$ light path). A diluted leaf extract was added to the solution to start the reaction.

The complete ascorbate peroxidase (EC 1.11.1.11) movement was estimated spectrophotometrically as indicated by Nakano and Asada (1981) by following the decrease in absorption at $290 \mathrm{~nm}$ as solution was oxidized ( $\mathrm{R}$ $\left.=2.8 \mathrm{mM}^{-1} \cdot \mathrm{cm}^{-1}\right)$. The pace of oxidation was assessed somewhere in the range of 1 and $60 \mathrm{~s}$ in the wake of beginning the response with the expansion of $\mathrm{H}_{2} \mathrm{O}_{2}$. The $1 \mathrm{~mL}$ reaction fluid contained $50 \mathrm{~mm}$ Hepes- $\mathrm{NaOH}(\mathrm{pH} 7.6), 0.22$ $\mathrm{mM}$ ascorbate and $1 \mathrm{~mm} \mathrm{H}_{2} \mathrm{O}_{2}$. The control reaction blend was set up without the enzyme. Amendments were made for the low, nonenzymatic oxidation of ascorbate by $\mathrm{H}_{2} \mathrm{O}_{2}$ and for the oxidation of ascorbate without $\mathrm{H}_{2} \mathrm{O}_{2}$. The activity was expressed in terms of units $(\mu \mathrm{mol}$ of oxidized ascorbate per min) per $\mathrm{mg}$ of protein. The total guaiacol peroxidase activity was determined following the increase in absorption at $470 \mathrm{~nm}$ by adding the enzyme solution to $2 \mathrm{~mL}$ of guaiacol $(0.5 \%)$ and hydrogen peroxide $(9 \mathrm{mM})$ in $\mathrm{K}$-phosphate buffer (50 mM, pH 7.0) (Fielding and Hall, 1978).

Statistical analysis. The techniques of ANOVA, coupled with orthogonal contrasts and mean comparison was employed to study differences 
between different treatments. Ducan's multiple range tests were employed for mean separation procedures.

\section{RESULTS}

Maximum efficiency of PSII. No significant changes were seen in the maximal quantum yield of PSII photochemistry $\left(\mathrm{F}_{\mathrm{v}} / \mathrm{F}_{\mathrm{m}}\right)$ measured in leaves adapted for dark in either Cenchrus ciliaris or Digitaria commutata water-stressed plants (Figure 1). Almost constant $F_{v} / F_{m}$ ratio was observed in both species, the figure was close to 0.80 .

Pigment content. Exposure to water stress was observed to decrease total chlorophyll content in both plants (Figure 2A). The percentage reduction in chlorophyll content observed in both species reached $\mathrm{ca}$. 28 and $23.4 \%$ in comparison to control, respectively. However, on the other end, water scarcity led to an increase of carotenoid content in plants (Figure 2B) in comparison to the controls, the increase recorded was around $50 \%$ in both Cenchrus ciliaris and Digitaria commutata.

Lipid peroxidation (MDA content) A nominal increase in lipid peroxidation was noticed in leaves of both species, and a significant difference was observed in MDA content between stressed and control plants in C. ciliaris (Figure 3).

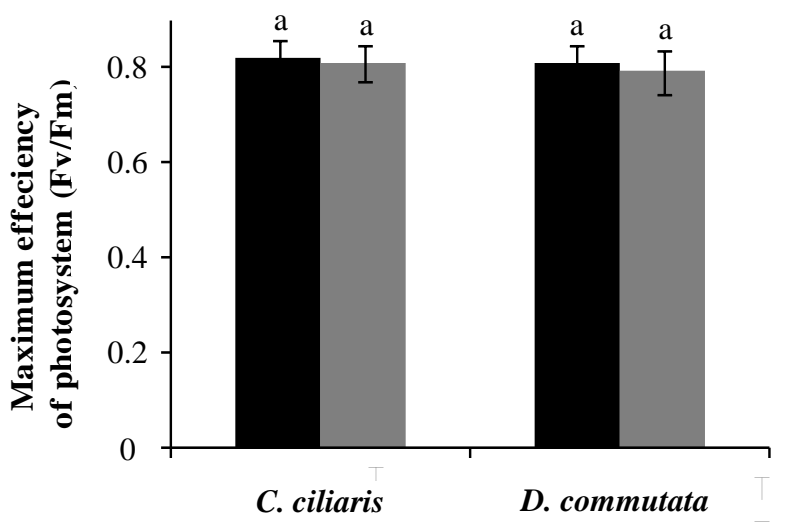

Figure 1. Means of maximal quantum yield of photosystem II (Fv/Fm) in Cenchrus ciliaris and Digitaria commutata leaves of control (black bars) and water stressed plants (gray bars). $\mathrm{n}=6$; bars indicate SE. Equal letters indicate no significant differences (Duncan test, $P>0.05$ )
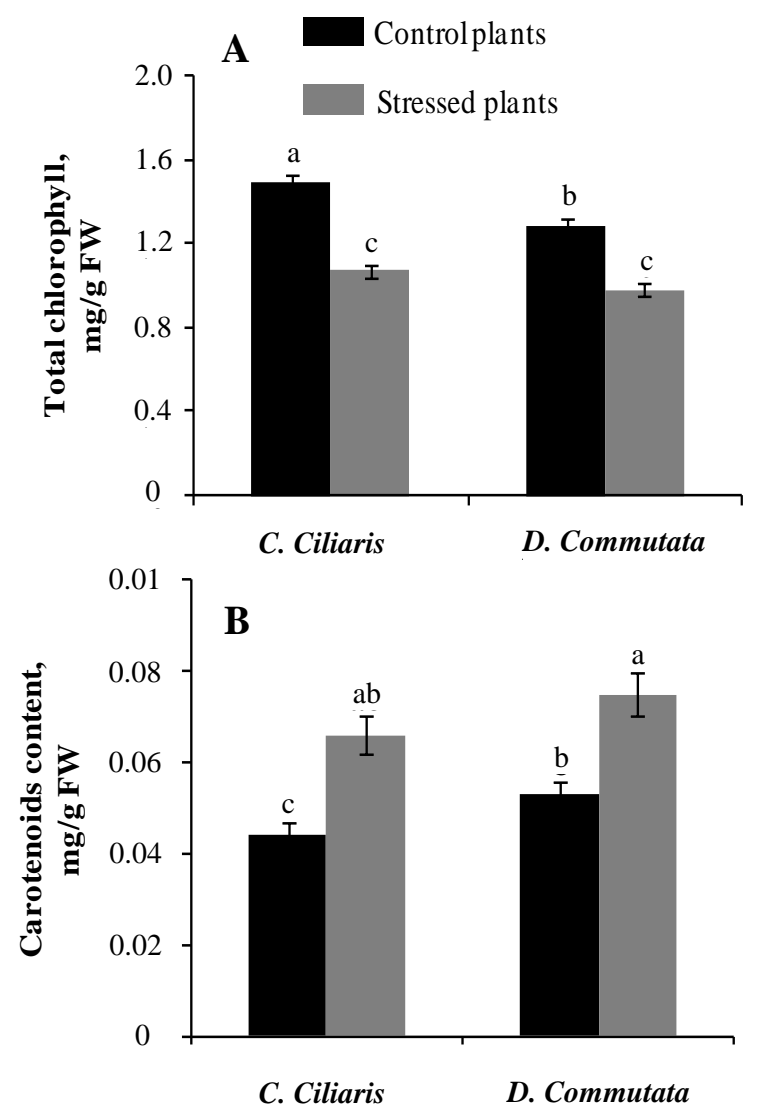

Figure 2. Means of total chlorophyll (A) and carotenoids (B) contents in leaves of Cenchrus ciliaris and Digitaria commutata subjected to water stress. $n=6$; bars indicate SE. Different letters indicate significant differences (Duncan test, $P \leq 0.05$ )

Leaf antioxidant enzymes activities. Responses of antioxidant enzyme activities in leaves of $C$. ciliaris and D. commutata seedlings are summarized in Table 1. Data shows the effects of irrigation treatments on CAT, APX and GPX activities. The activities of these enzymes in water stress were higher than control. Activity of CAT in both species increased significantly compared with control plants. CAT activity values recorded under water deficit were 37 and $34 \%$ higher than those of the control, for $C$. ciliaris and $D$. commutata, respectively. In treated plant, the ascorbate and guaiacol peroxidase activities also increased significantly in leaves and roots of both species. In contrast, for both species, the superoxide dismutase activity remained almost unchanged in water-stressed plants. 
Proline and soluble sugars content accumulation. Exposure to water stress augmented proline and sugars accumulation in leaves of Cenchrus ciliaris and Digitaria commutata. Proline level increased significantly in response to water deficit (Figure 4A), and there was also a significant accumulation of soluble sugars in leaf tissue of both species (Figure 4B).

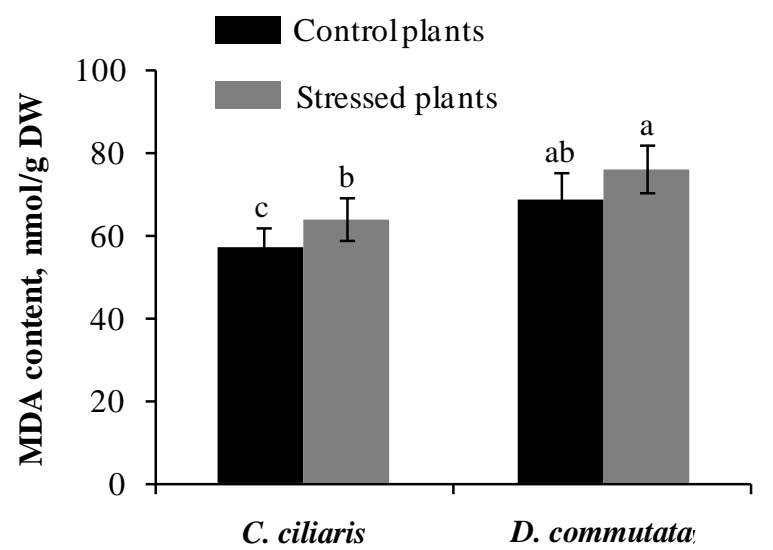

Figure 3. Means of Malondialdehyde (MDA) content on leaves of Cenchrus ciliaris and Digitaria commutata subjected to water stress. $\mathrm{n}=6$; bars indicate SE. Different letters indicate significant differences (Duncan test, $P \leq 0.05)$
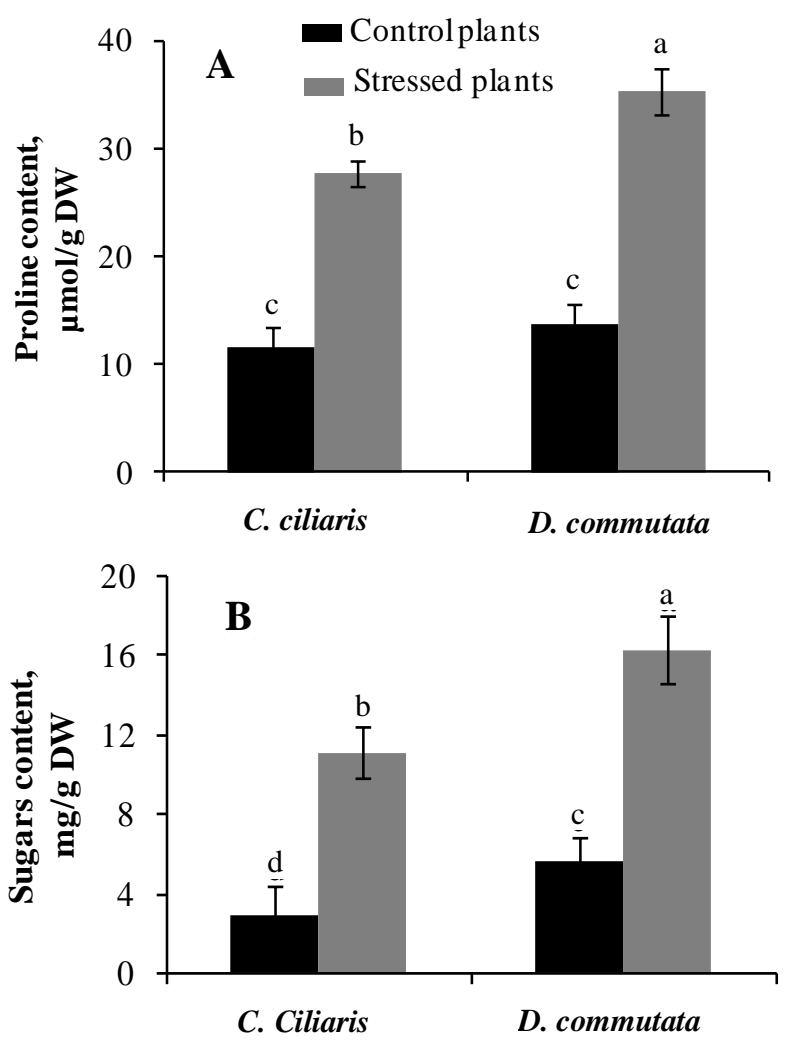

Figure 4. Means of proline (A) and total soluble sugars content (B) in leaves of Cenchrus ciliaris and Digitaria commutate subjected to water stress. $\mathrm{n}=6$; bars indicate SE. Different letters indicate significant differences (Duncan test, $P \leq 0.05$ )

Table 1. Catalase (CAT), Superoxide dismutase (SOD), Guaiacol peroxidase (GPX) and Ascorbate peroxidase (APX) activity of Cenchrus ciliaris and Digitaria commutata plants in response to water stress

\begin{tabular}{|c|c|c|c|c|}
\hline \multirow{2}{*}{ Treatment } & $\mathrm{CAT}\left(\mathrm{U} \cdot \mathrm{mg}^{-1}\right.$ protein $)$ & APX $\left(\mathrm{U}\right.$ protein $\left.\cdot \mathrm{min}^{-1}\right)$ & SOD $\left(\mathrm{U} \cdot \mathrm{mg}^{-1}\right.$ protein $\left.^{-1}\right)$ & GPX $\left(\mathrm{U} \cdot \mathrm{mg}^{-1}\right.$ protein $)$ \\
\hline & \multicolumn{4}{|c|}{ Leaves } \\
\hline \multicolumn{5}{|l|}{ C. ciliaris } \\
\hline Well-watered & $9.82 \mathrm{~b}$ & $39.64 \mathrm{~d}$ & $13.45 \mathrm{c}$ & $1.17 \mathrm{c}$ \\
\hline Stressed & $13.45 \mathrm{a}$ & $64.72 \mathrm{~b}$ & $27.39 \mathrm{a}$ & $2.19 \mathrm{~b}$ \\
\hline \multicolumn{5}{|l|}{ D. commutata } \\
\hline Well-watered & $8.81 \mathrm{~b}$ & $45.21 \mathrm{c}$ & $14.67 \mathrm{c}$ & $2.38 \mathrm{~b}$ \\
\hline \multirow[t]{2}{*}{ Stressed } & $11.79 \mathrm{ab}$ & $69.73 \mathrm{a}$ & $24.75 \mathrm{~b}$ & $3.76 \mathrm{a}$ \\
\hline & \multicolumn{4}{|c|}{ Roots } \\
\hline \multicolumn{5}{|l|}{ C. ciliaris } \\
\hline Well-watered & $4.12 \mathrm{a}$ & $17.81 \mathrm{~b}$ & $41.3 \mathrm{~b}$ & $0.97 \mathrm{~d}$ \\
\hline Stressed & $3.98 \mathrm{a}$ & $25.16 \mathrm{a}$ & $45.1 \mathrm{ab}$ & $3.23 \mathrm{a}$ \\
\hline \multicolumn{5}{|l|}{ D. commutata } \\
\hline Well-watered & $1.88 \mathrm{a}$ & $11.75 \mathrm{c}$ & $53.41 \mathrm{a}$ & $1.34 \mathrm{c}$ \\
\hline Stressed & $1.96 \mathrm{a}$ & $19.85 \mathrm{ab}$ & $52.90 \mathrm{a}$ & $2.71 \mathrm{~b}$ \\
\hline
\end{tabular}

Different letters in each column for each plant organ indicate significant difference according to Duncan's multiple range test $(P \leq 0.05)$ 


\section{DISCUSSION}

Total chlorophyll content of $C$. ciliaris and $D$. commutata was observed to decrease as a result of water scarcity (Figure 1). According to literature, the chlorophyll reduction could be due to altered chlorophyll metabolism or induced disintegration of the chloroplast molecules and the complex molecules of pigment-protein (Singh and Dubey, 1995). Yet, this does not seem to be the case in $C$. ciliaris and D. commutata. In spite of the fact that the reduction seen for chlorophyll content was generally significant, both plant species demonstrated a better ability to preserve the PSII functional integrity when tested against water deficiency. The efficiency of light utilization of PSII was observed to be unhinged by water stressexposure since $\mathrm{F}_{\mathrm{v}} / \mathrm{F}_{\mathrm{m}}$ ratio remained consistent over the course of treatment (Figure 2). The maximum efficiency of photosystem II was 0.80 , in line with levels observed in healthy plants (Maxwell and Johnson, 2000). Additionally, higher MDA content of water-stressed plants of both species, compared to control (Figure 3), demonstrated good ability of these species to preserve their membranes, especially chloroplast lipids, when exposed to water stress. Occurrence of complex membrane systems in chloroplasts rich in polyunsaturated fatty acids is a well-known fact. Hence these membranes are potential targets for ROS for peroxidation (Halliwell and Gutteridge, 1999).

With respect to chlorophyll concentration, the reduction could be due to altered chlorophyll metabolism. The lower pigment concentrations may be also due to the stress effect related cellular disorganization. Interestingly, chlorophyll loss was also described in some plants as a regulatory mechanism to reduce the amount of photons absorbed by leaves, conferring better photoprotection under stress.

Concerning the PSII integrity, plants develop a wide range of defense mechanisms involving enzymatic and non-enzymatic antioxidant systems, which can alleviate cellular oxidative damages. Several antioxidants protect higher plant cells from oxidative stress damage. They play crucial roles in scavenging ROS in the different cell compartments and in response to stress conditions. This supports their possible implication in preserve the PSII functional integrity when plants challenged with water stress.

Several mechanisms could contribute to crop drought tolerance. Among them, the enzymatic antioxidant system is an important defense system co-evolved with aerobic metabolism as a retort to water scarcity induced stress to counteract the ROS oxidative consequences. Indeed, enzymes which are antioxidant in nature such as, superoxide dismutase (SOD), guaicol peroxidase (GPX), ascorbate peroxidase (APX) and catalase (CAT) are notably implicated in the ROSscavenging and contribute towards the regulation of oxidation-reduction balance within the cells (Yin et al., 2008). For instance, SOD is a key enzyme which plays a crucial role in oxidative stress (Halliwell and Gutteridge, 1999). Through the regulation of superoxide levels, SOD plays a critical role in saving cells against oxidative damage, as they act as precursor for highly reactive oxygen derivatives, such as peroxynitrite or hydroxyl radical (Halliwell and Gutteridge, 1999).

In this study, exposure to water stress was observed to cause a significant increase in SOD activity in both species under examination (Table 1). Previous studies have observed a similar trend (Miller et al., 2010). CAT is a crucial antioxidant enzyme which plays a part in conversion of $\mathrm{H}_{2} \mathrm{O}_{2}$ to water and molecular oxygen (Arora et al., 2002). This is achieved through $\beta$-oxidation of $\mathrm{H}_{2} \mathrm{O}_{2}$ produced as a by-product of fatty acids and photorespiration (Nayyar and Gupta, 2006). Our results have shown an increase of the catalase activity in leaves of $C$. ciliaris and D. commutata, but it remained almost constant in the roots. Similar to our findings, increased CAT in Triticum aestivum plant subjected to water stress (Nayyar and Gupta, 2006) was found. Peroxidases constitute a family of enzymes (hemic) found in higher plants, facilitating various processes, such as lignification, linking of cell wall and auxin metabolism (Moussa and Abdel-Aziz, 2008). Therefore, SOD plays the main role in metabolic activity during growth alterations and abiotic stress. An increase in activity of APX and GPX was detected in leaves and roots of both species. Similar results were reported by Nayyar and Gupta (2006). However, the response seems to be related to the kind of stress. In a recent study, it 
was found that toxicity stress in rice caused lower activity of CAT, SOD, APX and GPX, although MDA showed higher content (Boorboori et al., 2020).

Increased level of activity of SOD and CAT might help plants in enduring extreme conditions of water scarcity. For example, increased CAT and APX activities reduced $\mathrm{H}_{2} \mathrm{O}_{2}$ level in cell and improved membranes stability and facilitated process of $\mathrm{CO}_{2}$ fixation because numerous enzymes involved in Calvin cycle in chloroplasts are very sensitive to $\mathrm{H}_{2} \mathrm{O}_{2}$ (Yamazaki et al., 2003). Under the extreme conditions of water stress, plants also synthesize solutes such as, proline and soluble sugars which helps them in drought resistance (Delatorre et al., 2010; An et al., 2013; Filippou et al., 2014; Ejaz et al., 2020). They are potent osmoprotectants that help to establish suitable osmotic pressure through involvement in osmotic adjustment which protects various sensitive cellular components and mitigates oxidation inside the cells by maintaining the cell turgor pressure (Silva et al. 2014). It has been suggested that compatible solutes do not affect normal biochemical reactions taking place in a cell and act as osmoprotectants during stress. Proline is one such osmolyte which is accumulated in water-stressed plants (Balibrea et al., 1999; Zhang et al., 2014). In this study, it was observed that the amount of proline and soluble sugars increased significantly in plants under water stress (Figure 4A-B). Delatorre-Herrera et al. (2010) and Hazrati et al. (2017) observed similar patterns and demonstrated that increased synthesis of these compounds, improves the efficiency of water usage in. Furthermore, the studies also suggested that proline and soluble sugars enable plants to overcome drought-induced stress through osmotic adjustment (DelatorreHerrera et al., 2010; Filippou et al., 2014; Hazrati et al., 2017).

Plants are also known to collect big amounts of potassium, a chief solute related to cellular osmotic water absorption and the preservation of cellular turgor (Hsiao and Läuchli, 1986). Likewise, a critical defensive function of carotenoids, a lipophilic pigment in chloroplasts, has been anticipated in the photosynthetic organism under stress conditions (Miller et al., 1996). Even though they're accessory pigment, carotenoids play a pivotal role in protective photochemical procedures and sustaining them (Asada, 1994). A primary defensive role of carotenoids in photosynthetic tissue can be via direct quenching of triplet chlorophyll, which prevents the generation of singlet oxygen and protects from oxidative damage (Mozzo et al., 2008). This study confirmed that leaf carotenoid content can expanded in stressed plant of $C$. ciliaris and $D$. commutata (Figure 2b). Those findings propose the viable implication of carotenoids in plant protection in opposition to drought.

\section{CONCLUSION}

Water stress decreased total chlorophyll content in plants of $C$. ciliaris and $D$. commutata. Interestingly, these species demonstrated a higher ability to preserve the PSII functional integrity when exposed to water stress. Our results show that increased SOD activity synced with changes in CAT and POD activities plays a critical defensive role in the ROS-scavenging process. The active participation of these enzymes is linked, at least in part, to drought-induced oxidative stress tolerance in $C$. ciliaris and $D$. commutata plants. The enhanced carotenoids, proline and soluble sugars accumulation in tissues support their possible implication in the osmotic adjustment which can help the plant to overcome drought stress.

\section{LITERATURE CITED}

1. Amari, T., I. Saidi, M. Taamali and C. Abdelly. 2017. Morphophysiological changes in Cenchrus ciliaris and Digitaria commutata subjected to water stress. International Journal of Plant Research 7(1): 12-20.

2. Armstrong, M.K. Jonscher and N.A. Reisdorph. 2007. Analysis of 25 underivatized amino acids in human plasma using ion-pairing reversed-phase liquid chromatography/time-offlight mass spectrometry. Rapid Communications in Mass Spectrometry 1: 2717-2726.

3. Arora, A, R.K. Sairam and G.C. Srivastava. 2002. Oxidative stress and antioxidative system in plants. Current Science 82: 1227- 
1238.

4. Asada, K. 1994. Production and action of active oxygen species in photosynthetic tissues In: C.H. Foyer and P.M. Mullineaux (eds.). Causes of photooxidative stress and amelioration of defense systems in plants. CRC Press. Boca Raton, FL, USA. pp 77-104.

5. Balibrea, M.E., M. Parra, M.C. Bolarin and F. Perez-Alfocea. 1999. PEG-osmotic treatment in tomato seedlings induces salt-adaptation in adult plants. Australian Journal of Plant Physiology 26: 781-786.

6. Boorboori, M.R., W. Lin, W. Zhan and C. Fang. 2020. The role of silicon to increase arsenic tolerance in rice (Oryza sativa L.) seedlings by reinforcing anti-oxidative defense. Bioagro 32(3): 159-168.

7. Bian, S. and Y. Jiang. 2009. Reactive oxygen species, antioxidant enzyme activities and gene expression patterns in leaves and roots of Kentucky blue grass in response to drought stress and recovery. Scientia Horticulturae 120: 264-270.

8. Chaieb, M. and M. Boukhris. 1998. Flore succinte et illustrée des zones arides et sahariennes de Tunisie. l'Or du Temps. Information Systems Division, National Agricultural Library. Washington DC.

9. Choudhury, S., P. Panda, L. Sahoo and S.K. Panda, S.K. 2013. Reactive oxygen species signaling in plants under abiotic stress. Plant Signal. Behav 8: e23681.

10.Delatorre-Herrera, J., I. Delfino, C. Salinas, H. Silva and L. Cardemil. 2010. Irrigation restriction effects on water use efficiency and osmotic adjustment in Aloe Vera plants (Aloe barbadensis Miller). Agricultural Water Management 97: 1564-1570.

11.Ejaz, S., S. Fahad, M.A. Anjum, A. Nawaz, S. Naz, S. Hussain and S. Ahmad. 2020. Role of osmolytes in the mechanisms of antioxidant defense of plants. Sustainable Agriculture Reviews 39: 95-117.

12. Demiral, T. and I. Türkan. 2005. Comparative lipid peroxidation, antioxidant defense systems and proline content in roots of two rice cultivars differing in salt tolerance. Environ. Exp. Bot. 53: 247-257.
13.La, V.H., B.R. Lee, Md. T. Islam, S. H. Park, H. Jung, D.W. Bae and T.H. Kim. 2019. Characterization of salicylic acid-mediated modulation of the drought stress responses: Reactive oxygen species, proline, and redox state in Brassica napus. Environ. Exp. Bot. 157: $1-10$.

14.Laxa, M., M. Liebthal, W. Telman, K. Chibani and J. Dietz. 2019. The role of the plant antioxidant system in drought tolerance. Antioxidants 8(4): 94.

15.Milvia, L.R. 2013. Antioxidant defenses in plants with attention to Prunus and Citrus spp. Antioxidants 2: 340-369.

16.Fang, Y., Y. Du, J. Wang, A. Wu, S. Qiao, B. $\mathrm{Xu}$ et al. 2017. Moderate drought stress affected root growth and grain yield in old, modern and newly released cultivars of winter wheat. Front. Plant Sci. 8: 672.

17.Fielding, J.L. and J.L. Hall. 1978. A biochemical and cytochemical study of peroxidase activity in roots of Pisum sativum. Journal of Experimental Botany 29: 979-986.

18. Filippou, P., P. Bouchagier, E. Skotti and V. Fotopoulos. 2014. Proline and reactive oxygen/nitrogen species metabolism is involved in the tolerant response of the invasive plant species Ailanthus altissima to drought and salinity. Environ. Exp. Bot. 97: 1-10.

19.Foyer, C.H. and G. Noctor. 2004. Oxygen processing in photosynthesis: regulation and signaling. New Phytologist 146: 359-388.

20.Gawel, S., M. Wardas, E. Niedworok and P. Wardas. 2004. Malondialdehyde (MDA) as a lipid peroxidation marker. Wiadomosci Lekarskie (Warsaw, Poland: 1960) 57(9-10): 453-455.

21.Genty, B., J.M. Briantais and R. Baker. 1989. The relationship between the quantum yield of photosynthetic electron and quenching of chlorophyll fluorescence. Biochimica et Biophysica Acta 99: 87-92.

22.Halliwell, B. and J.M.C. Gutteridge. 1999. Free Radicals in Biology and Medicine. Oxford Science Publications. New York.

23.Hazrati, S., Z. Tahmasebi-Sarvestani, A. Mokhtassi-Bidgoli, S.A.M., Modarres-Sanavy, 
H. Mohammadi and S. Nicola. 2017. Effects of zeolite and water stress on growth, yield and chemical compositions of Aloe vera L. Agricultural Water Management 181: 66-72.

24.Hodges, M.D. J.M. DeLong Forney F. R.K. Prange. 1999. Improving the thiobarbituric acid-reactive-substances assay for estimating lipid peroxidation in plant tissues containing anthocyanin and other interfering compounds. Planta 207: 604-611.

25.Hsiao, T.C. and A. Läuchli. 1986. A role of potassium in plant water relations. In: $\mathrm{B}$. Tinker and A. Läuchli (eds.). Advances in Plant Nutrition 2. Praeger Scientific. New York, pp. 281-312.

26.Lichtenthaler, H.K. and A. Welburn. 1983. Determination of total carotenoids and chlorophylls $\mathrm{a}$ and $\mathrm{b}$ of leaf extract in different solvents. Biochemical Society Transactions 603: 591-2.

27.Luck, H. 1965. Catalase. In: H.U. Bergmeyer (ed.). Methods of Enzymatic Analysis. Academic Press. New York. pp.: 885-888.

28.Manivannan, P., C. AbdulJaleel, R. Somasundaram and R. Panneerselvam. 2008. Osmoregulation and antioxidant metabolism in drought-stressed Helianthus annuus under triadimefon drenching. Comptes Rendus Biologies 331: 418-425.

29.Maxwell, K. and G.N. Johnson. 2000. chlorophyll fluorescence-a practical guide. Journal of Experimental Botany 51: 659668.

30.Miller, G., N. Suzuki, S. Ciftci-Yilmaz and R. Mittler. 2010. Reactive oxygen species homeostasis and signalling during drought and salinity stresses. Plant Cell \& Environment 33: 453-467.

31.Miller, N.J., J. Sampson, L.P. Candeias, P.M. Bramley and C.A. Rice-Evans. 1996. Antioxidant activities of carotenes and xanthophylls. FEBS Letters 384: 240-242.

32.Moussa, H. and S.M. Abdel-Aziz. 2008. Comparative response of drought tolerant and drought sensitive maize genotypes to water stress. Australian Journal of Crop Science 1: 31-36.
33.Mozzo, M., L. Dall'Osto R. Hienerwadel, R. Bassi and R. Croce. 2008. Photoprotection in the antenna complexes of photosystem II: Role of individual xanthophylls in chlorophyll triplet quenching. Journal of Biological Chemistry 283: 6184-6192.

34.Nakano, Y. and K. Asada. 1981. Hydrogen peroxide is scavenged by ascorbate-specific peroxidase in spinach chloroplast. Plant and Cell Physiology 22: 867-880.

35. Nayyar, H. and D. Gupta. 2006. Differential sensitivity of C3 and D4 plants to water deficit stress: Association with oxidative stress and antioxidant. Environmental and Experimental Botany 58: 106-113.

36.Pirasteh-Anosheh, H., A. Saed-Moucheshi, H. Pakniyat and M. Pessarakli. 2016. Stomatal responses to drought stress. In: Water Stress and Crop Plants: A Sustainable Approach. Wiley Blackwell. Oxford, UK. Volume 1.

37.Scebba, F., L. Sebastiani and C. Vitagliano. 1999. Protective enzymes against activated oxygen species in wheat (Triticum aestivum L.) seedlings: Responses to cold acclimation. Journal of Plant Physiology 155: 762-768.

38.Silva, H., S. Sagardia, M. Ortiz, N. Franck, M. Opazo, M. Quiroz et al. 2014. Relationships between leaf anatomy, morphology, and water use efficiency in Aloe vera (L.) Burm f. as a function of water availability. Revista Chilena de Historia Natural 87: 1-10.

39. Singh, A.K. and R.S. Dubey. 1995. Changes in chlorophyll $\mathrm{a}$ and $\mathrm{b}$ contents and activities of photosystems I and II in rice seedlings induced by $\mathrm{NaCl}$. Photosynthetica 31: 489-499.

40. Sturm, K., D. Koron and F. Stampar. 2003. The composition of fruit of different strawberry varieties depending on maturity stage. Food Chemistry 83: 417-422.

41. Yamazaki, J., A. Ohashi, Y. Hashimoto, E. Negishi, S. Kumagai, T. Kubo et al. 2003. Effects of high light and low temperature during harsh winter on needle photodamage of Abies mariesii growing at the forest limit on Mt. Norikura in Central Japan. Plant Science 165: 257-264.

42. Yin, H., Q. Chen and M. Yi. 2008. Effects of short-term heat stress on oxidative damage and 
responses of antioxidant system in Lilium longiflorum. Plant Growth Regulation 54: 45-54.

43.Zhang, L.X., J.H. Lai, Z.S. Liang and M. Ashraf. 2014. Interactive effects of sudden and gradual drought stress and foliar applied glycinebetaine on growth, water relations, osmolyte accumulation and antioxidant defense system in two maize cultivars differing in drought tolerance. Journal of Agronomy and Crop Science 200: 425-433. 